Leonarda Dacewicz

Uniwersytet w Białymstoku

Wydział Filologiczny

Kolegium Językoznawstwa

tel.: +48 857457499

e-mail: l.dacewicz@uwb.edu.pl

ORCID ID: https://orcid.org/0000-0001-5551-7208

\title{
Rozchwianie tradycji polskiej w zakresie nazewnictwa kobiet pod zaborem rosyjskim w kontekście historycznym i współczesnym
}

Słowa kluczowe: księgi metrykalne, antroponimia, formacje odmężowskie, formacje odojcowskie

Przyjęty w przeszłości zwyczajowo podział funkcji i ról społecznych mężczyzn i kobiet znalazł odzwierciedlenie w procesie kształtowania się polskiego systemu antroponimicznego. Zjawisko różnicowania się nazewnictwa ze względu na płeć pozostawało w bezpośrednim związku z uprzywilejowaną pozycją i wyłącznym udziałem mężczyzn w organizacji życia społecznego. W antroponimii dominacja męskości zaznaczyła się poprzez ekspansję funkcjonalną form męskich jako pierwotnych i podstawowych. Ponadto nazewnictwo męskie było wyżej notowane w hierarchii ważności, co wyrażało się m.in. tym, że formy żeńskie nazwisk zawsze tworzono od form męskich ${ }^{1}$.

W procesie rozwoju polskiego systemu nazewniczego wykształciły się formy nazwisk odmężowskich zakończone sufiksami - owa, -ina, -ska lub -a, np. Chodkiewiczowa, Niemierzyna, Popławska, Ladna (< Ładny). Nazwiska kobiet niezamężnych tworzono przy pomocy sufiksów -ówna (od podstaw

1 O dominacji nazwisk męskich w hierarchii ważności świadczą także pośrednio prace z zakresu antroponimii poświęcone wyłącznie nazewnictwu męskiemu (np. Citko 2001 i wiele innych). 
zakończonych na spółgłoskę), np. Chodkiewiczówna (< Chodkiewicz), -anka (od podstaw zakończonych na samogłoskę), np. Niemierzanka (< Niemiera), a w typach przymiotnikowych jak nazwiska mężatek, np. Popławska, Ladna. Formy z sufiksem - anka tworzono też od nazwisk na -ska, np. Popławszczan$k a(<\text { Popławska })^{2}$.

Formacje odmężowskie (andronimy) i formacje odojcowskie (patronimy) są przedmiotem szczególnej uwagi językoznawców poczynając od lat pięćdziesiątych XX wieku. Sprawa używania form przyrostkowych nazwisk żeńskich budziła żywe społeczne emocje, o czym świadczą prace wielu badaczy onomastów ${ }^{3}$. Dość intensywne zainteresowanie problematyką nazewnictwa kobiet m.in. wzięło się stąd, że społeczno-językowy zwyczaj (identyfikacja kobiet przy pomocy struktur odmężowskich i odojcowskich), który przyjął się i funkcjonował w Polsce ponad sześć wieków, na przestrzeni XX wieku stopniowo zaczął ulegać erozji ${ }^{4}$. W rezultacie uległ niemal całkowitemu zanikowi, zwłaszcza w środowiskach miejskich (Kaleta 1998, 111-117; Skudrzykowa 1996, 17-22).

Badania antroponimii Podlasia w XIX wieku wykazały, że proces widocznych zmian w nominacji kobiet zaczął się już wówczas.

Przedmiotem uwagi w niniejszym opracowaniu jest zjawisko maskulinizacji żeńskich form nazwisk w II połowie XIX wieku na obszarze północnej części polsko-wschodniosłowiańskiego pogranicza, która w znacznym stopniu obejmowała Podlasie. Problem będzie przedstawiony w kontekście historycznego rozwoju nazewnictwa kobiet na Podlasiu oraz ogólnej informacji na temat stanu nominacji żeńskiej w Polsce w czasach współczesnych. Obserwacje dotyczące rysującej się zmiany funkcji tradycyjnych żeńskich przyrostków nazwiskowych, a właściwie narzuconego przez obce władze wycofywania tych form $\mathrm{z}$ oficjalnego obiegu, jakie miało miejsce w okresie długiego okresu przynależności części ziem polskich do Rosji, z różnych powodów nie zostały dotąd należycie zbadane i opisane w historyczno-socjolingwistycznej perspektywie. A jest to zagadnienie ważne dla chronologicznego systemowego opisu procesu kształtowania się i funkcjonowania nazewnictwa kobiet w Polsce.

2 Przykłady nazwisk pochodzą z zasoby źródłowego historycznej antroponimii Podlasia (Dacewicz 1994).

3 Zob. Bibliografia w artykule A. Skudrzykowej (1996), m.in.: E. Pawłowski, K. Nitsch, M. Kucała, A. Markowski, K. Handke, B. Kreja. Ponadto: Skulina 1988; Dacewicz 1994, 2014; Kaleta 1998, 2007; Pelcowa 2001; Karwatowska 2005.

4 Formy odmężowskie zakończone sufiksami -owa, -ina są poświadczone w II połowie XIV wieku (Kowalik-Kaleta 2007, 343, 355). 
Opis zasygnalizowanego zjawiska będzie dokonany na bazie obfitego materiału źródłowego wyekscerpowanego z ksiąg metrykalnych kościoła rzymskokatolickiego trzech dekanatów wchodzących w skład dawnej diecezji wileńskiej (białostocki, grodzieński, sokólski) w latach 1875-1918. Zespół ksiąg metrykalnych chrztów, znajdujący się w zasobach Archiwum Archidiecezjalnego w Białymstoku, stanowi niezwykle cenne źródło do badania rozwarstwienia stanowego polskiego społeczeństwa, zwyczajów nazewniczych, wpływu rosyjskiej kultury nazewniczej na polskie nazewnictwo osobowe. Księgi są sporządzone w języku rosyjskim, który został wprowadzony do administracji kościelnej tych dekanatów w latach 1848-1849, bowiem w wyniku zawartego między cesarzem Napoleonem i carem Aleksandrem I w Tylży traktatu obszar Podlasia i Grodzieńszczyzny znalazł się w granicach Cesarstwa Rosyjskiego (Dobroński 2012, 224-226).

\section{Rys historyczny. Nazwiska kobiet na Podlasiu w XVI-XVII wieku ${ }^{5}$}

Określony powyżej obszar badawczy zamykał się w granicach historycznego Podlasia. Szczegółowe badania nazewnictwa wyekscerpowanego z szesnastowiecznych źródeł wykazały, że w owym czasie nazw kobiet derywowanych sufiksem - owa (również odnotowanych w wersji ruskiej - owaja) oraz sufiksem -ina (-inaja) używano we wszystkich warstwach społecznych, np. Hryniowa, Iwaszkowaja, zazwyczaj w połączeniu z określeniem wdowa. Natomiast ograniczony zasięg społeczny miały antroponimy derywowane wschodniosłowiańskim sufiksem -icha/-ycha i sufiksem - $k a$. Nazwy te funkcjonowały wyłącznie w warstwie chłopskiej, i być może wśród miejskiego plebsu (Dacewicz 1994, 133).

W XVII w. sposoby identyfikacji kobiet, odnotowane w dokumentach źródłowych, nadal cechowała znaczna różnorodność. Żeńskie nazwy osobowe, podobnie jak w wieku XVI, tworzono droga derywacji fleksyjnej od nazwisk męskich na -ski oraz drogą derywacji sufiksalnej od wszelkich pozostałych nazw męskich, tj. imion w pełnej lub hipokorystycznej formie, formacji odapelatywnych o genezie przezwiskowej i odzawodowej, formacji patronimicznych i przydomków. Nazwiska kobiet zamężnych tworzono przy pomocy sufiksów feminatywnych - owa, -ina, -icha/-ycha, -ka (Dace-

\footnotetext{
5 Autorka niniejszego opracowania wiele lat poświęciła badaniu antroponimii kobiet na polsko-wschodniosłowiańskim pograniczu (w tym Podlasie). Wyniki tych badań częściowo są wykorzystane w tym artykule do przedstawienia charakterystycznych cech antroponimii kobiet w XVI-XVIII wieku.
} 
wicz 1994). Formy derywowane sufiksami - anka, -ówna zwyczajowo określały córki. Niemniej jednak formacji odojcowskich używano także wówczas, gdy kobieta była już zamężna, a nawet gdy była wdową, często obok nazwiska odmężowskiego, np. stawetna Marusia Matesowna żona szlachetnego Krzystopka Niemirskiego (Dacewicz 1995a, 53-70; Dacewicz 1995b, 43-53; Dacewicz 2014, 266-267; 273).

\section{Nazwiska żon i córek na Podlasiu w XVIII wieku}

W źródłach odnoszących się do XVIII wieku największą frekwencję wykazywały nazwiska zakończone na -ska i - owa. W większych ośrodkach miejskich dominowały struktury z sufiksem -ska, np. Branicka, Niwińska, Sobolewska. Nazwiska tego typu przede wszystkim były odnotowane w księgach metrykalnych Kościoła rzymskokatolickiego. W środowiskach małomiasteczkowych, we wsiach, wyraźnie przeważały nazwiska kobiet utworzone przy pomocy sufiksu -owa, np. Adamczykowa, Markiewiczowa, Litwiniukowa, Przybyszowa. Ich uniwersalny charakter wyrażał się tym, że były powszechnie używane we wszystkich warstwach społecznych i w różnych grupach etnicznych, na co mogą wskazywać podstawy nazwisk, np. Wierzbowa (Wierzba), Hawrylukowa (wschsł. Hawryluk), Jaszczultowa (lit. Jaszczułt), Achmieciowa (tat. Achmet), Szulcowa (niem. Szulc), Lejbuszowa (żyd. Lejb) (Dacewicz 2014, 269). Marytonimiczna funkcja sufiksu -ina przejawiała się słabiej ze względu na ograniczoną łączliwość z podstawami nazwisk męskich, np. Sulibina $(<$ Suliba),

Wykorzystywane do tworzenia form odmężowskich przyrostki $-k a$, -icha/-ycha nie posiadały cechy uniwersalności i występowały znacznie rzadziej, np. Hawryluczka (<Hawryluk), Karpicha (<Karp), Kozaczycha $(<$ Kozak). Nazwy z sufiksem -ka oraz wschodniosłowiańskim -icha/-ycha, podobnie jak w poprzednich stuleciach, odnotowano tylko wśród przedstawicielek warstwy chłopskiej (Dacewicz 1995b, 43-53; Dacewicz 2003, 15-17). Z badań Tadeusza Skuliny wynika, że rozwój funkcji marytonimicznej w nazwach na -ka, -icha to proces późniejszego pochodzenia $(1988,248)$.

W XVIII wieku nadal zwyczajowo nazwiska córek tworzono przy pomocy sufiksów -anka, -ówna. Sufiks -ówna dodawano do nazwiska ojca zakończonego na spółgłoskę, np. Cieślukówna (<Cieśluk), Gilowna (< Gil), Stankiewiczówna (< Stankiewicz). Jak wynika ze źródeł, bardziej uniwersalny charakter miał w owym czasie sufiks - anka, bowiem łączono go zarówno z podstawami zakończonymi na samogłoskę, jak i na spółgłoskę. W podstawach nazwisk córek, derywowanych tym przyrostkiem, znajdziemy róż- 
ne typy nazwisk ojców, w tym także nazwiska na -ski, np. Bieganszczan$k a$ (< Biegański), Cudowszczanka (< Cudowski), Daniluczanka (< Daniluk), Gburanka (<Gbur), Konopczanka (<Konopka), Siekierczanka (Siekierka). Jednakże większą popularność wykazywały struktury z sufiksem -ówna. Oba te typy nazwisk odojcowskich służyły do identyfikacji panien we wszystkich warstwach społecznych (Dacewicz 2014, 270).

Nazewnictwo kobiet w XVIII w. odznaczało się wyraźną stabilnością i regularnością stosowania określonych formuł identyfikacyjnych. Systemowe stosowanie formacji marytonimicznych $\mathrm{w}$ polskim nazewnictwie kobiecym kształtuje się i utrwala od końca XIV wieku (Skulina 1988, 248). Upowszechnienie się tego sposobu nazywania kobiet łączyło się (czasowo) z rozwojem i stopniową stabilizacją dwustopniowego systemu identyfikacji osób. Wynikało to także z faktu, że zwyczajowo funkcjonowały nazwiska obejmujące całą rodzinę. W wielu przypadkach trudno było ustalić przynależność społeczną nosicielki nazwiska, bo w materiałach źródłowych nie ma określeń lub kontekstu wskazującego na pochodzenie danej osoby.

\section{Nazwiska kobiet równe nazwiskom męskim (bez tradycyjnych żeńskich przyrostków nazwiskowych)}

Nazwiska kobiet bez wykładników morfologicznych, sygnalizujących płeć żeńską nosicielki, sporadycznie można już spotkać w podlaskich źródłach z XVI i XVII wieku. Są to głównie nazwiska na -owicz/-ewicz. Występują łącznie z formą na -owa lub -icha utworzoną od imienia męża. Tego typu formuły identyfikacyjne odnosiły się do kobiet wdów, np. Stanisławowaja Janowicz 1528, Matejewaja Pawtowicz Udowa 1928, Suprunowa Kałabunowicz 1560, Iwanicha Kudzinowicz 1560, pani Janowa Kłaszewicz Jakubowska wdowa 1662, Jaroszowa Trocewicz Matżonka zesztego Jarosza Trocewicz 1686. Użycie męskiej formy nazwiska w odniesieniu do kobiety stało w bezpośrednim związku ze zmianą statusu społecznego. Nazwiska $\mathrm{w}$ formie męskiej, derywowane sufiksem - owicz, identyfikowały kobiety wdowy we wszystkich warstwach społecznych, ponieważ po śmierci męża wdowa, ze względów życiowych, na ogół uzyskiwała względną samodzielność, mogła sama zarządzać majątkiem lub prowadzić warsztat rzemieślniczy (Dacewicz 2014, 277).

W nielicznych dokumentach z XVII wieku można stwierdzić obecność nazwisk $\mathrm{w}$ formie męskiej równych etnonimom, apelatywom lub derywowanych od apelatywów, np. Justina Litwin 1674, Marianna Kotlarz 1667, Agnes Krasieniuk 1674 (Dacewicz 2014, 278). 
W XVIII w. nazwiska kobiet bez wykładników formalnych formy żeńskiej nadal należały do rzadkości. Konsekwentnie utrzymywała się tendencja do używania form odmężowskich z sufiksami -owa, -ina, -icha i odojcowskich derywowanych sufiksami -anka, -ówna. W okresie nieco późniejszym, pod zaborem pruskim, wśród nazwisk kobiet równych antroponimom męskim najliczniej były reprezentowane nazwiska pochodzenia obcego, np. $\mathrm{Ma}$ rianna Spicer, Barbara Szuman, wdowa Kraum, Magdalena Pichler virgine (Dacewicz 2014, 271).

\section{Nazwiska kobiet (dziewczynek) w księgach metrykalnych chrztów w okresie zaboru rosyjskiego na Podlasiu}

Przejście badanego terytorium pod panowanie Rosji pociągnęło za sobą wprowadzenie języka rosyjskiego do administracji kościelnej (Dacewicz 2015, 365). „W okresie zaborów obce władze wprowadziły zakaz używania końcówek nazwisk żon -owa, -ina oraz nazwisk córek derywowanych -ówna, -anka, -ska, -a (typ Czerna)" (Litwin 1932, 24; Kaleta 1998, 111). W związku z tym w nazewnictwie kobiet zaczęły się dokonywać zmiany. W jakim stopniu carski nakaz był stosowany w trzech badanych dekanatach w okresie niewoli narodowej? Odpowiedź na to pytanie wiąże się ze żmudną ekscerpcją dziewiętnastowiecznych ksiąg metrykalnych i analizą wielu notacji metrykalnych ${ }^{6}$.

Materiał do badań został wyekscerpowany z wybranych ksiąg metrykalnych trzech dekanatów (każdy liczył po kilkanaście parafii, np. w dekanacie białostockim w roku 1875 było 17 parafii, w 1880 i 1885 po 18 parafii), które znajdują się w Archiwum Archidiecezjalnym w Białymstoku.

Przedmiotem badań są przede wszystkim alfabetyczne imienne spisy ochrzczonych dzieci, które zaczęto wprowadzać jako obligatoryjną część zapisu metrykalnego od roku 1875.

Prawdopodobnie nie zalecono kancelariom parafialnym określonego wzorca zapisu ${ }^{7}$, bowiem w poszczególnych parafiach stosowano zróżnicowane sposoby ewidencji. Udało się wyodrębnić kilka typów struktur nazwiskowych i zestawień antroponimicznych, występujących w parafiach wymienionych dekanatów. Przeważnie stosowano mieszane sposoby identyfikacji, np.:

6 Charakterystyka treści i struktury ksiąg metrykalnych dekanatu białostockiego, grodzieńskiego i sokólskiego zob.: Dacewicz 2017; Dacewicz, Chomko, Smakulska 2017; Dacewicz, Romanik, Smakulska 2019).

7 Notacja metrykalna, która w okresie zaboru zajmowała dwie strony księgi, we wszystkich dekanatach była sporządzana według ściśle określonego wzorca. 
1) Nazwisko i imię dziecka, np. Шиманска Анна (1880, Par. Supraśl k. 237); Олехно Осипъ, Рутковска Юзефа (1885, Dek. Białystok Par. Goniądz k. 156-157).

2) Nazwisko, imię i imię odojcowskie (otčestwo) dziecka, np. Сосновска Юзефа Ивановна, Боровский Иванъ Ивановъ (1875, Par. Białystok k. 107); Бущьковна Марьянна Ивановна (1875, Dek. Sokółka Par. Korycin k. 212).

3) Nazwisko, imię dziecka oraz imiona rodziców, np. Бочковна Маріянна Сымона и Иозефы, Кирпша Иванъ Ивана и Розаліи (1875, Par. Sokółka k. 39-40).

4) Nazwisko, imię, syn/córka (czyja?), nр. Буйкова Маріянна дочъ Петра, Бовсюкъ Адамъ сынъ Петра (1880, Grodno, Par. Franciszkańska); Куликовна Антонина дочъ Михала (1890, Grodno, Par. Farna); Якубовичъ Паулина дочъ Петра (1885, Dek. Białystok, Par. Dobrzyniewo k. 562-564).

5) Nazwisko, imię (po kim?), imię ojca, np. Жукъ Петръ nо Петру (1875, Dek. Sokółka, Par. Suchowola k. 319).

6) Nazwisko rodziców w dop. l. mn. i imię dziecka, np. Жьихаровъ Ельжбљта, Жилюковъ Леонъ (1880, Grodno Par. Pobernardyńska).

W znacznie mniejszym stopniu do badań nazewnictwa kobiet można wykorzystać imienne alfabetyczne spisy poślubionych i zmarłych, m.in. z powodu niższej pozycji społecznej kobiet, co wyrażało się tym, że w spisach poślubionych w niektórych parafiach podawano tylko nazwisko i imię nowożeńca, np. Арбузъ Михаилъ, Гилевский Осипъ... (1876, Dek. Białystok Par. Goniądz k. 660), kobiety nie uczestniczyły w ceremonii ślubnej jako świadkowie; w notacji metrykalnej zgonu dziecka należało podać tylko informację, kto był ojcem ${ }^{8}$.

Na podstawie przeglądu alfabetycznych imiennych spisów ochrzczonych dzieci można stwierdzić, że sposoby imiennej identyfikacji dziewczynek były zróżnicowane i odznaczały się pewnym stopniem dowolności polegającej na stosowaniu różnych struktur nazwiskowych nawet w spisie tej samej parafii w tym samym roku. W zbiorze wszystkich typów struktur nazwiskowych używanych do identyfikacji dzieci płci żeńskiej, wyekscerpowanych z badanych źródeł, można wyodrębnić następujące antroponimy:

- nazwiska derywowane sufiksem - ska, np. Яроика Юзефа (1885, Dek. Białystok Par. Supraśl k. 235v); Врублевска Людвика дочь Якова (1885,

8 Informacje uzyskane w wyniku ekscerpcji licznych alfabetycznych spisów osób z wielu parafii dekanatu białostockiego. 
Grodno Par. Franciszkańska k. 165), Каминска Анна дочъ Феофила (1890, Grodno Par. Farna k. 16), w tym często w rosyjskiej wersji -skaja, np. Bpoчинская Ева (1885, Dek. Białystok Par. Trzcianne k. 253);

- formacje odojcowskie utworzone przy pomocy sufiksu -ówna (w rosyjskim zapisie -оwna/-еwna), np. Госковна Бронислава, Левковичовна Михалина (1885, Dek. Białystok Par. Trzcianne k. 253), Куликовапа Антонина дочь Михаила (1890, Grodno Par. Farna k. 16).

- formacje z sufiksami -оwa/-еwa, np. Годунова Елисавета Иванова, Жакова Мария Сильвестрова (1880, Dek. Białystok Par. Knyszyn k. 436), Зимнохова Антонина (1875, Dek. Białystok Par. Suraż k. 484); Серафиновичева Марьянна (1880, Grodno Par. Pobernardyńska k. 62). Z dokładnej analizy nazwisk żeńskich wynika, że użycie formacji z sufiksem - owa/-ewa, zwyczajowo identyfikujących kobiety zamężne, w imiennych spisach chrztów niektórych parafii były głównie wskaźnikiem żeńskości. Ich stosowanie nie miało na celu rozróżnianie statusu cywilnego. Takie przypuszczenie potwierdzają liczne użycia nazwisk na -owa w odniesieniu do kobiet niezamężnych, w przypadku alfabetycznych spisów ochrzczonych osób do dziewczynek;

- nazwiska w formie męskiej, czyli bez formalnych wykładników żeńskości odnotowano w spisach wielu parafii, np. w parafii białostockiej: Дворжанчикъ Софія Осиповна (1875, k. 108); Зеневичь Казимира Викентіевна, Филончукъ Катерина Антоновна (1880, k. 163); Гилъ Стефанія Ивановна, Мальико Александра Ивановна, Огродникъ Анна Владиславовна, w tym także nazwiska obce, np. Ральфъ Констанция Константиновна (1885, k. 155-157); Ядешко Стефанія (1885, Dek. Białystok Par. Dolistowo k. 323v). Liczne nazwiska, identyfikujące osoby płci żeńskiej, podano w formie męskiej w spisach parafii Knyszyn, np. Bopouuло Мария Викентьева, Лазарчикъ Михалина Антонова Мороз Мария Семенова (1875, k. 306-310); Гавелко Оршуля Иванова. Новикъ Михалина Мартиновна Снопко Анастазия Антоновна (1880, k. 430-435); Гердо Мария Ивановна, Корольчук Мариеля Осиповна, Шульиъ Марьянна Карловна (1885 k. 436-440).

Zwracają uwagę imienne spisy parafii Dolistowo i Turośń z 1875 roku, w których do identyfikacji kobiet użyto nawet męskich form nazwisk z sufiksem -skij, nр. Малиновскій Розалія, Милевскій Сузанна, Янковскій Стефанія (1875, Par. Dolistowo k. 271); Гловачкій Јозефа, Зайковскій Людвика, Кучинский Катерина (1875, Par. Turośń k. 271). Użycie takich struktur może świadczyć o nadgorliwości w przestrzeganiu obowiązującego wówczas rozporządzenia o identyfikacji kobiet przy pomocy męskich form nazwisk. 
Z drugiej zaś strony rozporządzenie urzędów carskich zapewne nie było przestrzegane rygorystycznie, bowiem w spisach kilku parafii z roku 1875 form męskich nazwisk do identyfikacji kobiet jeszcze nie używano, odnotowano tylko struktury z sufiksem -ska i -оwa, np. Данильчукова Людвика, Поплавска Анна (Dek. Białystok Par. Suraż k. 484) oraz w rosyjskiej wersji -skaja, -ошаја, np. Конецкая Вероника, Мрочковая Александра (Dek. Białystok Par. Trzcianne k. 239), co jednak dowodzi, że rusyfikacja miała miejsce.

Interesujący przypadek stanowią spisy parafii Juchnowiec z 1875 i 1885 roku (w 1880 spisu nie sporządzono), w których wyraźnie jest widoczny trend do zachowania polskości. Oczywistym tego przejawem są odnotowane w spisie nazwiska z wykładnikami żeńskości, czyli nazwiska kobiet derywowane sufiksami -ska, -оwna, -ówna (zapis ros. -увна), пр. Гловацка Анна, Леончуковна Паулина, Тарасюкувна Антонина, i brak form męskich. Niemniej jednak widoczny jest udział sufiksów w wersji rosyjskiej, np. w spisie parafii Trzcianne z 1875 roku nazwiska kobiet są opatrzone sufiksem -skaja, np. Чайковская Анна, і -ошаја, nр. Клепадловая Анна, w roku 1880 sufiksami -skaja (częste), np. Багинская Марьянна, Плонская Амелия, -ошаја (pojedyncze), nр. Шишковая Анна, i formy męskie (częste), np. Клепадло Виктория, Крукъ Марьянна, Рожко Констанчия, ale w roku 1885 oprócz struktur z sufiksem -skaja (częste), np. Боровская Марьянна, Жуковская Софья, odnotowano liczne typowe nazwiska odojcowskie z sufiksem -оwna, nр. Шорцовна Альбина, Гайдовна Cтепания, a formy męskie sporadycznie, nр. Кобешко Марьянна, Цильвик Степания.

Z biegiem lat nazwiska kobiet $\mathrm{w}$ formie męskiej stopniowo zastępowały formacje zawierające wykładniki żeńskości. Na podstawie wybranych spisów z 1900 roku można stwierdzić, że dominowały dwie struktury: nazwiska na -ska, przeważnie w wersji rosyjskiej - skaja, oraz formy męskie, np. Buuневская Марія, Адамовичъ Марія (Par. Białystok k. 255-256); Павловская Бронислава, Морозъ Франиишка (Grodno Par. Franciszkańska k. 192). Rzadziej dodatkowo notowano formy z sufiksem - owna i - owa/-ewa, nр. Янушевская Геновефа, Зайчева София, Кононовичъ Бронислава (Grodno Par. Farna k. 64v, 66v); Шумска Валерия, Мисарковна Зофия, Дзешко Иозефата (Dek. Sokółka Par. Suchowola k. 236v, 237, 238); Pymковска Софья, Вальчуковна Фелииия k. 67 (Dek. Białystok Par. Goniądz k. 67, 69); Воронечкая Геновефа Викентьева, Јашковна Софья Фаддева (Par. Sokółka k. 55, 56).

Warto zadać pytanie, co było powodem wprowadzenia przez administrację rosyjską zakazu używania tradycyjnych nazwisk z wykładnikami żeńsko- 
ści -owa, -ina, -ówna, -anka na zaanektowanym terytorium. Tym bardziej, że rosyjskie nazwiska żeńskie mają w swej strukturze sufiksy -owa, -ina. Raczej potrzeby praktyczne, czyli unifikacja form gramatycznych $\mathrm{w}$ celu wyeliminowania trudności związanych z ich tworzeniem, czy cele polityczne - zacieranie śladów polskiej tradycji narodowej?

\section{Okres międzywojenny}

Po odzyskaniu niepodległości nastąpił powrót do form tradycyjnych, przypuszczalnie częściowo ze względów patriotycznych, tęsknoty za dawno utraconą przeszłością, też jako sprzeciw wobec narzuconej woli obcego państwa.

Wprowadzony przez administrację rosyjską nakaz używania do identyfikacji kobiet męskich form nazwisk zniósł Sejm II Rzeczpospolitej na mocy ustawy z dnia 1 sierpnia 1919 roku. Po odzyskaniu niepodległości motywacją do przywrócenia form nazwisk żeńskich było przekonanie, że ich zlikwidowanie przez zaborców było niekorzystne dla „narodowości polskiej” (Litwin 1932, 24). Dzięki tej ustawie powrócono do tradycji sięgającej średniowiecza, gdyż w Polsce formy te powstały i były używane dla oznaczenia żon i córek od drugiej połowy XIV wieku (Kaleta 1998, 111-112).

W okresie międzywojennym regionalne urzędy wojewódzkie wydawały rozporządzenia nakazujące używanie form żeńskich nazwisk podając reguły ich tworzenia i wykazy przykładów (Litwin 1932, 24-31; Kaleta 1998, 111). I tak nazwiska kobiet zamężnych miały kończyć się na - owa, -ina, -ska lub -a, np. Głowacka, Wieczorkowa, Zarębina. Nazwiska kobiet niezamężnych miały kończyć się na -ówna lub -anka, np. Wieczorkówna, Zarębianka, a w typach przymiotnikowych jak nazwiska mężatek, np. Żelazna. Reguły te dotyczyły także nazwisk obcych, np. Goldbergowa, Goldberżanka. W świetle historii obyczajów polskich takie reguły wynikały z roli, jaką kobieta miała pełnić w społeczeństwie. Powszechnie uważano, że przeznaczeniem kobiety było wyjść za mąż i mieć dzieci. Pozostając w pewnej zależności majątkowej i prawnej od męża, jak twierdzi Zofia Kaleta, żona zapewne z dumą nosiła nazwisko na -owa lub -ina świadczące o tym, że jest mężatką (Kaleta 1998,144$)$.

Jednakże, jak wynika z analizy dokumentów Kościoła katolickiego w tym konkretnym przypadku ksiąg metrykalnych chrztów, po odzyskaniu niepodległości nie powrócono w pełni do tradycji polskiej w zakresie nazewnictwa kobiet. W księgach metrykalnych dekanatu białostockiego, grodzieńskiego i sokólskiego w roku 1918 do rejestracji ochrzczonych dziewczynek 
oprócz nazwisk na -ska używano męskich form nazwisk, np. Sawicka Władysława, Cieślak Marja (Par. Białystok k. 66, 68). Ten sposób zapisu kontynuowano, o czym świadczą przykłady z roku 1930, np. Galicka Krystyna, Dunaj Antonina Krystyna (k. 111), w parafii grodzieńskiej farnej Roszko Zofja (k. 118), w parafii sokólskiej Bagan Janina Kazimierza (k. 40). Badane źródła zawierają setki zarejestrowanych nazwisk w formie męskiej, które służyły do identyfikacji kobiet. Ostrożnie można stwierdzić, że w administracji kościelnej nie powrócono do stosowania nazwisk z wykładnikami żeńskości, jak zalecały urzędy państwowe, bowiem Kościół zawsze wprowadzał zmiany ostrożnie i bez pośpiechu.

\section{Druga połowa XX wieku}

Kolejne zmiany polityczne, społeczne, ekonomiczne i kulturowe, które nastąpiły po drugiej wojnie światowej, uruchomiły nieuchronny proces odchodzenia od nazwisk kobiet z wykładnikami żeńskości. W drugiej połowie XX wieku nastąpiła zmiana funkcji tradycyjnych żeńskich przyrostków nazwiskowych. Charakter zmian strukturalnych w nazewnictwie kobiet, ich przyczyny, zakres funkcjonalny opisała m.in. Aldona Skudrzykowa (1996, 17-23). W polszczyźnie ogólnej zakończenia tworzące nazwiska kobiet niezamężnych są współcześnie bardzo rzadkie, sporadycznie już tylko używane (głównie w środowiskach artystycznych, dziennikarskich). Często nie wskazują na stan wolny nosicielki, lecz są wykładnikiem żeńskości i znakiem pewnego snobizmu, przynależności środowiskowej do elity artystycznej. „Jeśli przyrostki -anka, -ówna wykorzystuje się do tworzenia nazwisk kobiet, to nie pełnia już one w zasadzie swej pierwotnej funkcji: nie tworzac nazwisk panien, kobiet niezamężnych". W sposób neutralny, zgodny z tradycją, nazwiska żeńskie na -owa funkcjonują jeszcze w pokoleniu najstarszym oraz w języku pewnych, bardzo już rzadkich środowisk inteligenckich średniego pokolenia, tych, które pielęgnują tradycyjną polszczyznę kulturalną (Skudrzykowa 1996, 19-23).

Zdecydowanie zmniejszyło się użycie przyrostka -ina (Markowski 1972, 413). Natomiast funkcja przyrostka - owa daleka jest od pierwotnej: jest on głównie wykładnikiem żeńskości. „We współczesnym poczuciu językowym w neutralny nienacechowany sposób nazwiska typu Nowakowa w języku ogólnym funkcjonować mogą w typie kontaktu lokalnego (sytuacja półoficjalna), raczej w postaci mówionej, zarówno w rozmowach między nadawcą i odbiorcą realizujących równorzędne role społeczne, jak i nierównorzędne role społeczne" (Skudrzykowa 1996, 20). 
W podsumowaniu należy stwierdzić, że w kontakcie oficjalnym ogólnonarodowym neutralnym wariantem nazwiska żeńskiego jest jego postać męska, zwłaszcza w pokoleniu średnim i młodszym. Jak wykazały badania dotyczące obszaru dawnego Podlasia, proces maskulinizacji zaczął zataczać coraz szersze kręgi już w drugiej połowie XIX wieku, przede wszystkim za sprawą władz zaborczych, niemniej jednak był to wyrazisty trend narodowy i kulturowo-społeczny. Potwierdziły się więc przypuszczenia Bogusława Krei, który biorąc pod uwagę działalność urzędów państw zaborczych stwierdził, że wpływ na przemiany polskiej tradycji nazewniczej mogły mieć języki obce $(1995,12-22)$. Niewątpliwie był to jeden z istotnych czynników. Jednakże wpływ ten był wzmocniony innymi czynnikami. Na przestrzeni II połowy XX w. zmieniła się zhierarchizowana struktura polskiej rodziny. Nadrzędna funkcja ojca przestała być jednoznacznie oczywista. Przyrostki - owa, -ina i -ówna, -anka były językowym wykładnikiem podporządkowania, przynależności żony i córki. „Drugorzędna” rola kobiet w domu i społeczeństwie stała w sprzeczności z ich dążeniem do emancypacji, równouprawnienia. Aktywność zawodowa, społeczna i publiczna kobiet spowodowała, że nazwisko wyszło z obiegu prywatnego, domowego, potocznego do obiegu oficjalnego, i dlatego przyjęło właśnie taką oficjalną formę.

\section{Literatura}

Citko L., 2001, Nazewnictwo osobowe pótnocnego Podlasia w XVI w., Białystok.

Dacewicz L., 1994, Nazewnictwo kobiet $w$ dawnym powiecie mielnickim (XVIXVII w.), Białystok.

Dacewicz L., 1995a, Nazewnictwo żeńskie dawnego woj. podlaskiego w porównaniu z historyczna antroponimia białoruska, „Białostocki Przegląd Kresowy”, t. III, Białystok, s. 53-70.

Dacewicz L., 1995b, Nazewnictwo żeńskie dawnego powiatu mielnickiego w porównaniu z historyczna żenska antroponimia ukrainska, (w:) Kontakty językowe polsko-wschodniosłowiańskie, Rzeszów, s. 43-53.

Dacewicz L., 2003, Z historii nazwisk na polsko-wschodniostowiańskim pograniczu kulturowym (wiek XVI-XVIII), (w:) Nazwy własne a kultura. Polska i inne kraje słowiańskie. Prace Slawistyczne 115, red. Z. Kaleta, Warszawa, s. $11-19$.

Dacewicz L., 2014, Historia nazwisk na kresach pótnocno-wschodnich Rzeczpospolitej (XVI-XVIII w.), Białystok 2014.

Dacewicz L., 2015, Rusyfikacja nazewnictwa osobowego w katolickich ksiegach metrykalnych Dekanatu białostockiego w okresie zaboru (lata 1896-1918), „Slavia Orientalis", t. 64 , nr 2, s. 363-374. 
Dacewicz L., 2017, Księi metrykalne dekanatu Białystok, Grodno, Sokótka z drugiej połowy XIX w. jako źródła do historii społeczeństwa polsko-wschodniostowiańskiego pogranicza, (w:) Archiwalne dziedzictwo. Białostockie Studia Archiwalno-Kościelne, t. XVIII, red. tomu ks. A. Szot, Białystok.

Dacewicz L. Chomko J., Smakulska J., 2017, Ksiegi metrykalne chrztów Kościoła rzymskokatolickiego z II połowy XIX wieku. Treść i struktura metryk. Alfabetyczne spisy imienne, Część 1. Rok 1875, Białystok.

Dacewicz L., Romanik A., Smakulska J., 2019, Księgi metrykalne chrztów Kościoła rzymskokatolickiego z II połowy XIX wieku. Treść i struktura metryk. Alfabetyczne spisy imienne, Tom 2. Rok 1880, Białystok.

Dobroński A. (red.), 2012, Historia Białegostoku, Białystok.

Kaleta Z., 1998, Nazwisko w kulturze polskiej, Warszawa.

Kowalik-Kaleta Z., 2007, Historia nazwisk polskich. Na tle społecznym i obyczajowym (XII-XV wiek), t. I, Warszawa.

Litwin J., 1932, Imię i nazwisko, Łódź.

Kreja B., 1995, Językowe i pozajęzykowe przyczyny nieodmienności polskich nazwisk, „Język Polski” LXXV, s. 12-22.

Markowski A., 1972, Odmiana nazwisk we współczesnej polszczyźnie, „Poradnik Językowy", z. 6, 7, s. 351-359, 406-415.

Nitsch K., 1951, Uwagi o nazwiskach kobiet zamężnych i panien, „Język Polski” XXXI, s. 62-68.

Skudrzykowa A., Nazwiska żeńskie z przyrostkiem -owa we wspótczesnej polszczyźnie ogólnej, „Język Polski” LXXVI 1, s. 17-23.

Skulina T., 1988, O staropolskich formacjach marytonimicznych, (w:) V Ogólnopolska Konferencja Onomastyczna, red. K. Zierhoffer, Poznań, s. 241-248.

\section{Źródła}

Księgi metrykalne chrztów dekanatu białostockiego z lat 1875-1918 (w wyborze). Archiwum Archidiecezjalne w Białymstoku (dalej AAB).

Księgi metrykalne chrztów dekanatu grodzieńskiego z lat 1875-1918 (w wyborze). $\mathrm{AAB}$.

Księgi metrykalne chrztów dekanatu sokólskiego z lat 1875-1918 (w wyborze). $\mathrm{AAB}$.

Księgi metrykalne chrztów dekanatu grodzieńskiego z lat 1875-1918 (w wyborze). AAB.

Księgi metrykalne chrztów dekanatu sokólskiego z lat 1875-1918 (w wyborze). AAB.

Przykładowe oryginalne tytuły ksiąg:

Выписи Метрической книги Белостокской Римско-Католической Приходской Церкви Часть первая О Родившихся съ 1 числа Января мљ* сяца 1885 года. 
Выписи Метрической книги Занеменско-Гродненской Францишканской Римско-Католической Приходской Церкви за 1875 годъ. Часть первая О Родившихся.

Księgi metrykalne chrztów parafii białostockiej, grodzieńskiej i sokólskiej z 1930 roku. AAB.

\section{Rozwiązanie skrótów}

Dek. - dekanat

k. - karta

lit. - litewski

niem. - niemiecki
Par. - parafia

tat. - tatarski

wschsł. - wschodniosłowiański

żyd. $\quad-$ żydowski

\section{SHAKING OF THE POLISH TRADITION IN TERMS OF NAMING WOMEN UNDER RUSSIAN RULE IN THE HISTORICAL AND CONTEMPORARY CONTEXT}

\section{ABSTRACT}

The customary division of functions and social roles of men and women adopted in the past was reflected in the process of shaping the Polish anthroponymic system. The phenomenon of differentiation of nomenclature based on gender was directly related to the privileged position and exclusive participation of men in the organization of social life. In anthroponymy, the domination of masculinity is marked by the functional expansion of male forms as primary and basic. Male nomenclature was higher listed in the hierarchy of importance, female forms of surnames were always created from male forms. The surnames of married women were ending with the suffixes - owa, -ina, -ska or -a, e.g. Chodkiewiczowa, Niemierzyna, Popławska, Ladna. The surnames of unmarried women were created using the suffixes -ówna (ending in a consonant from scratch), e.g. Chodkiewiczówna (<Chodkiewicz), -anka (ending in a vowel from scratch), e.g. Niemierzanka $(<$ Niemiera), and in adjective types like married surnames, for example, Popławska, Ladna.

The subject of attention in this study is the phenomenon of masculinization of female surname forms during the Russian partition (second half of the 19th century) in the Podlasie region. The problem is presented in the context of the historical development of women's nomenclature in Podlasie and general information on the state of female nomination in Poland in modern times.

Key words: record books, anthroponymy, post-marital formations, paternal formation, transformations 